\title{
Ventilation with Risk Quotient (RQ) Benzene Non-Carcinogen in The Shoes Home Industry of Romokalisari, Surabaya
}

\author{
Ratna Ayu Harsetianingrum ${ }^{1}$, Abdul Rohim Tualeka ${ }^{2}$ \\ ${ }^{1}$ Department of Occupatioanl Health and Safety, ${ }^{2}$ Public Health Faculty, Airlangga University, Surabaya
}

\begin{abstract}
The objectives of this study were to identify the presence of ventilation, Risk Quotient (RQ) of benzene noncarcinogen and the relationship between them in the shoes home industry of Romokalisari, Surabaya. Type of study was observational, cross sectional analytics with 10 workers as total population.

Data analysis was using cross tabulation to know the frequency of ventilation and Risk Quotient (RQ), that obtained from the value of Intake benzene non karsinogen (Ink), benzene concentration in work environment $(\mathrm{C})$, inhalation rate $(\mathrm{R})$, length of work/day (tE), working frequency/year (fE), duration of work (Dt), worker's weight $(\mathrm{Wb})$ and average time period $\left(\mathrm{t}_{\mathrm{avg}}\right.$ ). Analysis relationship between ventilation with Risk Quotient (RQ) of benzene non carcinogen was using Chi-Square Test and Prevalence Risk (PR).

The results obtained most of the workplace were not ventilated ( 9 places $(90 \%))$. Concentrations of benzene in the environment $0.04 \mathrm{mg} / \mathrm{m}^{3}-2.91 \mathrm{mg} / \mathrm{m}^{3}$. Inhalation rate (R) $0.5 \mathrm{~m}^{3} / \mathrm{hr}-0.7 \mathrm{~m} / \mathrm{hr}$. Length of work per day (tE) 8 hours/day-15 hours/day. Frequency of work per year (fE) 312 days/year-365 days/year. Duration of work (Dt) 14 years-43 years. Weight of worker (Wb) in 8 people $(80 \%) \leq 70 \mathrm{Kg}$. RfC benzene $0.03 \mathrm{mg} /$ $\mathrm{m}^{3}$. Risk Quotient $(\mathrm{RQ})>1$, indicating that there was a possibility of non-carcinogenic health risks. P-value was 0.035 , meaning there was relationship between the existence of ventilation with the Risk Quotient (RQ) benzene non-carcinogen in workers. Prevalence Risk (PR) was 9.000, meaning that the absence of ventilation has a risk 9 times greater for the risk of non-carcinogen health effects. Recommendations were by making good ventilation in the workplace and consuming CYP2E1 enzyme contained in cow liver and salmon to lower benzene levels in the body. ${ }^{13}$
\end{abstract}

Keywords : Benzene, Ventilation, Risk Quotient, Workers, Shoes Home Industry

\section{INTRODUCTION}

Benzene is widely used as a good organic solvent for various industrial processes such as rubber industry, shoes, paint solvents, components in motor fuel, components in detergents, pesticides and pharmaceutical manufacturing. ${ }^{3}$ The US-EPA has classified benzene as a carcinogenic substance against humans (GrupA), so now the use of benzene as a solvent is increasingly constrained. ${ }^{20}$

In general, people can smell benzene from concentrations of $60 \mathrm{ppm}$ to $100 \mathrm{ppm}$ and to feel benzene in water at concentrations of 0.5 to $4.5 \mathrm{ppm} .{ }^{7}$ Based on Permenakertrans Nomor Per.13/MEN/X/2011 about Threshold Limit of Physical Factor and Chemical Factors at Work, maksimum benzene exposure is $1.59 \mathrm{mg} /$ $\mathrm{m}^{3},{ }^{12}$ American Conference of Governmental Industrial Hygienists (ACGIH) states the limit of benzene exposure is $0.5 \mathrm{ppm}$ with maximum exposure for 8 hours of work, ${ }^{1}$ while the American Petroleum Institute (API) states that the absolute limit of safe exposure to benzene is zero. ${ }^{14,16}$

Continuous exposure to benzene and exceeding predetermined threshold values can cause adverse health effects, especially exposure through inhalation. The impacts that can arise from acute exposure to benzene can cause disruption of the nervous system, lack of oxygen supply to the brain, dizziness, rapid heartbeat, headache, tremors, confusion and fainting. ${ }^{18,19}$ Benzene toxicity to the central nervous system arises after exposure to benzene through inhalation/respiration with high concentrations (3,000 ppm for 5 minutes) or 30 to 
60 minutes via digestion. ${ }^{3}$

Based on the study previously about benzene and affect to the body have not been conducted study about effect ventilation to the risk quotient yet. As non formal Industry, shoes industry should to know effect ventilation to RQ worker for preventing disease by benzene.

The shoes home industry of Romokalisari, Surabaya is a small shoes manufacturing sector in Surabaya. In the production process in the shoes home industry of Romokalisari, Surabaya there is the process of gluing shoes with the use of glue materials in which there is a chemical content of benzene. In addition, the presence of ventilation in the shoes home industry of Romokalisari, Surabaya allegedly can affect the level of exposure of benzene in the workplace. Therefore, the study aims to determine the existence of ventilation, Risk Quotient (RQ) of benzene non-carcinogen and the relationship between the existence of ventilation with Risk Quotient (RQ) benzene non-carcinogen in home industry shoes Romokalisari, Surabaya.

\section{MATERIALS AND METHOD}

This study was an observational study with cross sectional analytical design in home industry of shoes Romokalisari Surabaya with total population counted 10 workers. This study was conducted at home industry of shoes Romokalisari, Surabaya in October 2017.

Variables in this study were the presence of ventilation and Risk Quotient (RQ) of benzene noncarcinogen. Determination of Risk Quotient (RQ) of benzene non-carcinogen was calculated from Intake benzene non-carcinogen $\left(\mathrm{I}_{\mathrm{nk}}\right) / \mathrm{RfC}$. The value of Intake benzene non-carcinogenic was the result of calculation that was directly proportional to the value of benzene concentration in the working environment $(\mathrm{C})$, inhalation rate of worker (R), length of work/day (tE), working frequency per year (fE), duration of work (Dt) and was inversely proportional to the worker's characteristic value (consisting of worker's weight $(\mathrm{Wb})$ and average time period $\left(\mathrm{t}_{\mathrm{avg}}\right)$.

Primary data collection included the presence of ventilation data and worker characteristics (worker's weight $(\mathrm{Wb})$, length of work / day (tE), working frequency every year (fE), duration of work (Dt)). Secondary data collection included benzene concentration value data in work environment $(\mathrm{C})$, worker inhalation rate $(\mathrm{R})$ and average time period $\left(\mathrm{t}_{\text {avg }}\right)$ used for non-carcinogen intake benzene $\left(\mathrm{I}_{\mathrm{nk}}\right)$ and $\mathrm{RfC}$ value used to calculate Risk Quotient (RQ).

Data analysis was using cross tabulation to know the frequency of the presence of ventilation and frequency of value to determine Risk Quotient (RQ) of benzene non-carcinogen that is result of calculation from Intake benzenenon-carcinogen $\left(\mathrm{I}_{\mathrm{nk}}\right) / \mathrm{RfC}$. To determine the value of non-carcinogen intake benzene $\left(\mathrm{I}_{\mathrm{nk}}\right)$, it was necessary to know the frequency of benzene concentration values in the work environment $(\mathrm{C})$, inhalation rate of worker (R), length of work/day (tE), frequency of work each year (fE), working duration (Dt), worker's characteristic value (consisting of worker's weight $(\mathrm{Wb})$ and average time period $\left(\mathrm{t}_{\mathrm{avg}}\right)$. The relationship analysis of the presence of ventilation with Risk Quotient (RQ) of benzene non-carcinogen was using Chi-Square Test and to know the amount of risk was using Prevalence Risk (PR).

\section{FINDINGS}

\section{The Presence of Ventilation}

Based on Table. 1 below, it could be seen that most of the place workers to work in the shoes home industry of Romokalisari, Surabaya had no ventilation that was counted 9 places $(90 \%)$.

Tabel 1. Distribution of The Presence of Ventilation at Worker's Place in The Shoes Home Industry of Romokalisari, Surabaya

\begin{tabular}{|l|l|l|}
\hline The Presence of Ventilation & N & \% \\
\hline Yes & 1 & 10,0 \\
\hline No & 9 & 90,0 \\
\hline Total & $\mathbf{1 0}$ & $\mathbf{1 0 0 , 0}$ \\
\hline
\end{tabular}

Based on Peraturan Menteri Kesehatan Republik Indonesia No. 48 in 2016 about Occupational Safety and Health Standards in Office, it said that one of the requirements of building safety and security was the availability of ventilation for circulation and air exchange needs, especially when there were equipment that used solvent such as benzene. In addition, based on Keputusan Menteri Kesehatan Republik Indonesia Nomor 1405/MENKES/SK/XII/2002 in 2002 about the Health Working Environment Requirements in the Office and Industry, it said that every office space and industry had to had air/ventilation holes. Standard air 
exchange was $0.283 \mathrm{~m}^{3} / \mathrm{min} /$ person with ventilation rate of 0.15 to $0.25 \mathrm{~m} / \mathrm{s}$. For non-cooling working rooms should had a ventilation hole at least $15 \%$ of the floor area by applying a cross ventilation system. ${ }^{11}$

LEED $^{10}$, ASHRAE ${ }^{2}$, and $\mathrm{ICC}^{9}$, suggested that additional ventilation at the end of construction would reduced VOC concentrations (including benzene) to acceptable levels. In indoor environmental studies, BRE reported that seasonal variation in indoor air concentrations was due to higher concentrations of exterior air infiltrated to buildings, and a greater effect of indoor sources during the winter than in the summer months. This wass because the available ventilation at a low/bad level. ${ }^{4}$ VOC concentrations including benzene are reduced when the level of ventilation and material emission standards were met. ${ }^{8}$

\section{Risk Quotient (RQ) of Benzene Non-Carcinogen}

The following on the below were data of benzene concentration, inhalation rate, worker characteristics, non-carcinogenic benzene intake and Risk Quotient (RQ) in the shoes home industry of Romokalisari, Surabaya.

Tabel. 2 Data of Benzene Concentration, Inhalation Rate, Workers Characteristic, Intake Benzene NonCarcinogen and Risk Quotient (RQ) of Benzene Non-Carcinogen in The Shoes Home Industry of Romokalisari, Surabaya

\begin{tabular}{|l|l|l|l|l|l|l|l|l|l|}
\hline $\begin{array}{l}\text { No. } \\
\text { Workers }\end{array}$ & $\begin{array}{l}\mathbf{C} \\
\mathbf{m g} / \mathbf{m}^{3}\end{array}$ & $\begin{array}{l}\mathbf{R} \\
\mathbf{m}^{3} \mathbf{j} \mathbf{j a m}\end{array}$ & $\begin{array}{l}\mathbf{t E} \\
\mathbf{J a m} / \mathbf{h a r i}\end{array}$ & $\begin{array}{l}\mathbf{f E} \\
\text { Hari/Tahun }\end{array}$ & $\begin{array}{l}\mathbf{D t} \\
\mathbf{T a h u n}\end{array}$ & $\begin{array}{l}\mathbf{W b} \\
\mathbf{K g}\end{array}$ & $\begin{array}{l}\mathbf{t}_{\text {avg }} \\
\text { Hari }\end{array}$ & $\begin{array}{l}\mathbf{I}_{\text {nk }} \\
\mathbf{m g} / \mathbf{K g} / \\
\mathbf{h a r i}\end{array}$ & $\begin{array}{l}\mathbf{R Q} \\
\mathbf{m g} / \mathbf{K g} / \\
\mathbf{h a r i}\end{array}$ \\
\hline 1. & 1.12 & 0.5 & 13 & 312 & 43 & 42 & 10950 & 0.2285 & 26.8785 \\
\hline 2. & 1.12 & 0.6 & 9 & 312 & 43 & 52 & 10950 & 0.1390 & 16.3475 \\
\hline 3. & 0.06 & 0.6 & 14 & 312 & 36 & 50 & 10950 & 0.0099 & 1.1686 \\
\hline 4. & 0.06 & 0.6 & 8 & 312 & 40 & 48 & 10950 & 0.0065 & 0.7608 \\
\hline 5. & 1.27 & 0.7 & 10 & 350 & 27 & 70 & 10950 & 0.1019 & 11.9865 \\
\hline 6. & 1.27 & 0.6 & 8 & 365 & 20 & 50 & 10950 & 0.0781 & 9.1863 \\
\hline 7. & 1.27 & 0.7 & 8 & 312 & 14 & 80 & 10950 & 0.0345 & 4.0540 \\
\hline 8. & 1.27 & 0.6 & 15 & 365 & 23 & 53 & 10950 & 0.1624 & 19.1039 \\
\hline 9. & 2.91 & 0.7 & 10 & 312 & 25 & 85 & 10950 & 0.1691 & 19.8992 \\
\hline 10. & 0.04 & 0.7 & 15 & 365 & 20 & 70 & 10950 & 0.0037 & 0.4375 \\
\hline Average &
\end{tabular}

In Table. 2 above, the value of Intake benzene noncarcinogenic $\left(\mathrm{I}_{\mathrm{nk}}\right)$ can be calculated using the following formula:

Intake Benzene Non - Carcinogen $=\frac{\mathrm{C} \times \mathrm{R} \times \mathrm{tE} \times \mathrm{fE} \times \mathrm{Dt}}{\mathrm{Wb} \times \mathrm{Tavg}}$

Based on the calculation of Intake benzene noncarcinogen $\left(\mathrm{I}_{\mathrm{nk}}\right)$ value above, it was known that the maximum intake value received by workers in the shoes home industry Romokalisari Surabaya was $0.2285 \mathrm{mg} /$ $\mathrm{Kg} /$ day).

$$
\text { Risk Quotient }(R Q)=\frac{\text { Intake }}{R f C}
$$

Risk Quotient (RQ) of benzene non-carcinogen determines benzene exposure having non-carcinogenic risks in the worker's body or not. The value of Risk Quotient (RQ) is calculated using the following formula:

It was known that the non-carcinogenic benzene RfC values established by US-EPA ${ }^{21}$ are $0.03 \mathrm{mg} / \mathrm{m}^{3}$ or $0.0085 \mathrm{mg} / \mathrm{Kg} /$ day. Based on the calculation table above, the average value of Risk Quotient (RQ) on workers in the shoes home industry of Romokalisari, Surabaya was $10.9823 \mathrm{mg} / \mathrm{Kg} /$ day and the highest RQ was 26.8785 $\mathrm{mg} / \mathrm{Kg} /$ day. This showed that $\mathrm{RQ}>1$, meaning that there was a possible indication of the risk of non-carcinogenis health effect and the need for control measures. ${ }^{15}$ 
This was in accordance with the results of study that conducted by Edokpolo, Yu and Conneli ${ }^{5}$ on the Health Risk Assessment for Exposure to Benzene in Petroleum Refiney Environments, found that $\mathrm{RQ}>1$ for scenarios $2 \mathrm{~A}$ and $3 \mathrm{~A}$ indicating possible health risks for groups exposed to benzene. A study conducted by Fahrudi ${ }^{6}$ on the Risks of Cancer and Non-Cancer at Benzene Exposure Workers in Home Industry Shoe Kelurahan Oso Wilangun Surabaya, found that benzene levels measured in the workplace air ranged from $0.04 \mathrm{mg} /$ $\mathrm{m}^{3}$ to $7.44 \mathrm{mg} / \mathrm{m}^{3}, \mathrm{RQ} \leq 1$ was counted 8 people $(40 \%)$, RQ $>1$ was counted 13 people $(60 \%)$ and ECR calculation got all workers with ECR value $>10^{-5}$ was counted 20 people (100\%).

The Presence of Ventilation with Risk Quotient (RQ) of Benzene Non-Karsinogen

In the bivariate analysis of the relationship between the presence of ventilation with Risk Quotient (RQ) of benzene non-carcinogen, the Risk Quotient (RQ) variable was made in 2 values, that were $R Q \leq 1$ and $R Q>1$ in the Prevalence Risk (PR) calculation. The following below was relationsip between the presence of ventilation with Risk Quotient (RQ) of Benzene Non-Carcinogen.

Tabel. 3 Relationship between The Presence of Ventilation with Risk Quotient (RQ) of Benzene NonCarcinogen The Shoes Home Industry of Romokalisari, Surabaya

\begin{tabular}{|c|c|c|c|c|c|c|c|c|}
\hline \multirow{3}{*}{ The Presence of Ventilation } & \multicolumn{4}{|c|}{ Risk Quotient (RQ) } & \multirow{2}{*}{\multicolumn{2}{|c|}{ Total }} & \multirow{3}{*}{ p-value } & \multirow{3}{*}{$\begin{array}{c}\text { Prevalence Risk } \\
\quad(95 \% \mathrm{CI})\end{array}$} \\
\hline & \multicolumn{2}{|c|}{$\mathrm{RQ} \leq \mathbf{1}$} & \multicolumn{2}{|c|}{$\mathrm{RQ}>1$} & & & & \\
\hline & $\mathbf{N}$ & $\%$ & $\mathbf{N}$ & $\%$ & $\mathbf{N}$ & $\%$ & & \\
\hline Yes & 1 & 10.0 & 0 & 0.0 & 1 & 10.0 & \multirow{3}{*}{0.035} & \multirow{3}{*}{$\begin{array}{c}9.000 \\
(1.418-57.1117)\end{array}$} \\
\hline No & 1 & 10.0 & 8 & 80.0 & 9 & 90.0 & & \\
\hline Total & 2 & 20.0 & 8 & 80.0 & 10 & 100.0 & & \\
\hline
\end{tabular}

Based on the results in Table. 3 above, it was found that the $\mathrm{p}$-value of the relationship between the presence of ventilation with Risk Quotient (RQ) of benzene noncarcinogen was 0.035 and when compared with $\alpha$ that was 0.005 then p-value 0.035 was smaller than $\alpha$ so it could be seen that there was a relationship between the presence of ventilation with Risk Quotient (RQ) of benzene non-carcinogen in the shoes home industry of Romokalisari, Surabaya.

Prevalence Risk (PR) showed 9.000, meaning that the absence of ventilation was 9 times greater risk for non-carcinogen health effects $(\mathrm{RQ}>1)$ to workers in the shoes home industry of Romokalisari, Surabaya and there was a significant relationship between the presence of ventilation and the value Risk Quotient (RQ) to worker in the shoes home industry of Romokalisari, Surabaya which could be seen from PR value does not pass $1(1,418-57,1117)$.

These results were consistent with the theory expressed by $\mathrm{LEED}^{10}$, $\mathrm{ASHRAE}^{2}$, and $\mathrm{ICC}^{9}$, suggesting that additional ventilation at the end of construction would reduce VOC concentrations (including benzene) to acceptable levels. VOC concentrations including benzene were reduced when ventilation levels and material emission standards were met. ${ }^{8}$ According to the
Tokyo National Institute of Technology and Evaluation, indoor benzene concentrations were usually higher than in the open air which could be caused by the entry and accumulation of benzene from external sources and the presence of dominant benzene sources indoors. ${ }^{17}$

\section{CONCLUSION}

The result of study found out that most of places $(90.0 \%)$ for workers to work did not had ventilation. The most of worker in the shoe home industry of Romokalisari, Surabaya had Risk Quotient (80.0\%) more than 1 . There was a significant relationship between the presence of ventilation with Risk Quotient (RQ) of benzene non-carcinogen in the shoes home industry of Romokalisari, Surabaya ( $\mathrm{p}$-value $=0.035$, Prevalence Risk $=9.000)$. Recommendation were by making ventilation in a good workplace and by consuming CYP2E1 enzyme contained in beef liver and salmon that serves to lower benzene levels in the body. ${ }^{13}$

Conflict of Interest: All authors have no conflicts of interest to declare.

Source of Funding: This is an article "Ventilation with Risk Quotient (RQ) Benzene Non-Carcinogen in The Shoes Home Industry of Romokalisari, Surabaya" of Occupational Health and Safety Department that was 
supported by Activity Budget Plans 2018, Faculty of Public Health, Airlangga University.

Ethical Clearance: The study was approved by the institutional Ethical Board of the Public Health, Airlangga University.

\section{REFERENCE}

1. ACGIH. Threshold limit values for chemical substances and physical agents and biological exposure indices. Cincinnanti: American Conference of Governmental Industrial Hygienists; 2014. p. $1-13$.

2. ASHRAE. Standard for the design of highperformance green buildings (ASHRAE 189.12014). US: ASHRAE and US Green Building Council; 2014.

3. ATSDR. Toxicological profile for benzene. USA: U.S. Departement of Public Health and Human Services; 2007.

4. Crump DR. Indoor air pollution. In: Davison $\mathrm{G}$, Hewitt $\mathrm{CN}$, eds. Air pollution in the United Kingdom. Cambridge, UK: The Royal Society of Chemistry; 1997.

5. Edokpolo B. Yu QJ, Conneli D. Health risk assess ment for exposure to benzene in petroleum refiney environments. Int. J. Envorin. Res. Public Health. 2015; 2: p. 595-610.

6. Fahrudi H. Risiko menderita kanker dan nonkanker pada pekerja terpapar benzene di home industry sepatu Kelurahan Oso Wilangun Surabaya. The Indonesian Journal of Occupational Safety and Health. 2017; 6(1): p. 68-77.

7. Fessenden R, Fessenden J. Kimia organik, $3^{\text {rd }}$ edition. Jakarta: Penerbit Erlangga; 1991. p. 122124.

8. Hult E, Willem H, Price P, Hotchi T, Russell M, Singer B. Formaldehyde and acetaldehyde exposure mitigation in U.S. Residences: In-home measurements of ventilation control and source control. Indoor air. Wiley Online Library. 2014; 25(5): p. 523-535.

9. ICC. International green construction. Washington, DC: ICC; 2013.

10. LEED. Rating system selection guide. Washington, DC: U.S. Green Building Council; 2016.

11. Menteri Kesehatan RI. Keputusan menteri kesehatan republik indonesia nomor 1405/MENKES/SK/
XII/2002 tentang persyaratan kesehatan lingkungan kerja perkantoran dan industri. Jakarta: Kementrian Kesehatan RI; 2002.

12. Menteri Tenaga Kerja dan Transmigrasi. Peraturan menteri tenaga kerja dan transmigrasi nomor Per.13/ MEN/X/2011 tahun 2011 tentang nilai ambang batas faktor fisika dan faktor kimia di tempat kerja. Jakarta: Kemenakertrans RI; 2011.

13. Nirmawati S, Tualeka AR, Adi AN. Effect of food containing high $\mathrm{Fe}$ (iron) intake to urinary trans, trans-muconic acid (Tt-ma) levels on workers exposed to benzene. Indian Journal of Public Health Research \& Development. 2018; 9(1): p. 53-57.

14. Pudyoko S. Hubungan pajanan benzene dengan kadar fenol dalam urine dan gangguan sistem hemapoetic pada pekerja instalasi BBM. Thesis. Semarang: Universitas Diponegoro; 2010.

15. Rahman A. Public health assessmen. Model kajian prediktif dampak lingkungan dan aplikasinya untuk manajemen risiko kesehatan. Depok: Pusat Kajian Kesehatan Lingkungan dan Industri FKM UI; 2007.

16. Ramon A. Analisis paparan benzene terhadap profil darah pada pekerja industri pengolahan minyak bumi. Thesis. Semarang: Magister Kesehatan Lingkungan Universitas Diponegoro Semarang; 2007.

17. Tokyo National Institute of Technology and Evaluation. Development of initial risk assessment method for chemical substances and preparation of the initial risk assessment. Annual report. Tokyo: National Institute of Technology and Evaluation; 2003.

18. Tunsaringkarn T, Prueksasit T, Kitwattanavong M, Siriwong W, Sematong S, Zapuang K, Rungsiyothin A. Cancer risk analysis of benzene, formaldehyde and acetaldehyde on gasoline station workers. Journal of Environmental Engineering and Ecological Science. 2012; p. 1-6.

19. Udonwa NE, Uko EK, Ikpeme BM, Ibanga IA, Okon BO. (2009). Exposure of petrol station attendants and auto mechanics to premium motor sprit fumes in Calabar, Nigeria. J. Environ. Public Health. 2009; p. 1-5.

20. US-EPA. Carcinogenic effects of benzene: An update. Prepared by the national center for environmental health, office of research and development. Washington, DC: US EPA; 1998.

21. US-EPA. Benzene (CASRN 71-43-2). Washington, DC: Irish, US EPA; 2015. 